Article

\title{
Combined Treatment (Alkali + Thermal) of Calotropis procera Fiber for Removal of Petroleum Hydrocarbons in Cases of Oil Spill
}

\author{
Raoni Batista dos Anjos *, Larissa Sobral Hilário (D), Aécia Seleide Dantas dos Anjos, \\ Emily Cintia Tossi de Araújo Costa, Tarcila Maria Pinheiro Frota, Amanda Duarte Gondim \\ and Djalma Ribeiro da Silva
}

check for updates

Citation: dos Anjos, R.B.; Hilário, L.S.; dos Anjos, A.S.D.; de Araújo Costa, E.C.T.; Frota, T.M.P.; Gondim, A.D.; da Silva, D.R. Combined Treatment (Alkali + Thermal) of Calotropis procera Fiber for Removal of Petroleum Hydrocarbons in Cases of Oil Spill. Polymers 2021, 13, 3285. https://doi.org/10.3390/ polym13193285

Academic Editor: Sunghyun Nam

Received: 30 August 2021

Accepted: 22 September 2021

Published: 26 September 2021

Publisher's Note: MDPI stays neutral with regard to jurisdictional claims in published maps and institutional affiliations.

Copyright: (c) 2021 by the authors. Licensee MDPI, Basel, Switzerland. This article is an open access article distributed under the terms and conditions of the Creative Commons Attribution (CC BY) license (https:/ / creativecommons.org/licenses/by/ $4.0 /)$.
Nucleus of Primary Processing and Reuse of Produced Water and Waste, Federal University of Rio Grande do Norte, Natal 59078-970, RN, Brazil; larissasobralhilario@yahoo.com.br (L.S.H.); aeciadantas@gmail.com (A.S.D.d.A.); emily.tossi@gmail.com (E.C.T.d.A.C.); tarcilafrota10@gmail.com (T.M.P.F.); amandagondim.ufrn@gmail.com (A.D.G.); djalmarib@gmail.com (D.R.d.S.)

* Correspondence: raonianjos@gmail.com; Tel.: +55-084-98191-1876

\begin{abstract}
The objective of this study was to evaluate the Calotropis procera fiber treated with $\mathrm{NaOH}$ combined with heat treatment as sorbent material for removal of petroleum and derivatives in cases of oil spill. The effects of oil viscosity, fiber/oil contact time, and the type of sorption system (oil and oil/water) were evaluated by experimental planning. The fiber obtained was characterized by Fourier transform infrared spectroscopy (FTIR), field-emission scanning electron microscopy (SEM-FEG), thermogravimetric analysis (TG/DTG), contact angle, and wettability. The fiber treated by combining $\mathrm{NaOH}$ and heat treatment $(\mathrm{CPNaOHT})$ exhibited a large structure with an internal diameter of $42.99 \pm 3.98 \mu \mathrm{m}$, roughness, and hydrophobicity on the surface with a contact angle of $101 \pm 2^{\circ}$. The sorption capacity of oil ranged from $190.32 \mathrm{~g} / \mathrm{g}$ to $98.9 \mathrm{~g} / \mathrm{g}$. After five cycles of recycling, the fiber still maintains about $70 \%$ of its initial sorption capacity and presented low liquid desorption $(0.25 \mathrm{~g})$. In this way, it can be used as an efficient sorbent to clean up spills of oil and oil products.
\end{abstract}

Keywords: sorption; petroleum; paraffin; oil spill; experimental planning; Calotropis procera

\section{Introduction}

Although statistics show a decrease in the number of accidents involving oil spills at sea, they continue to occur, threatening the environmental quality of coastal ecosystems such as beaches, rocky shores, and mangroves, among others [1,2]. In 2019, on the coast of northeastern Brazil, an oil spill reached a coastal strip of $4334 \mathrm{~km}$ in 11 states in the Northeast and Southeast, reaching 120 municipalities and 724 localities [3,4].

In accidents with this level of commitment, it is necessary to establish and employ efficient cleaning procedures. Therefore, the choice of procedures is essential to minimize impacts and accelerate the recovery processes of contaminated environments [5].

The most common oil spill containment method is the use of barriers containing sorbent materials with characteristics of high mechanical resistance and adequate physicochemical properties, such as polyurethane foams and polypropylene fibers. These materials, which have a high production cost and are non-biodegradable, have been widely used in the remediation of oil spill scenarios due to their high oil retention capacity, which can be more than 70 times the weight of the material itself [6-9]. Given this scenario, there is a demand for efficient and low-cost renewable materials for oil removal in cases of oil spills.

Rice husks, mandacaru, sawdust, and sugarcane bagasse, among other biomasses, have the advantages of low cost, easy availability, and biodegradability [10-12]. However, natural organic materials have the disadvantages of low selectivity and oil sorption efficiency. Some vegetable fibers with a tubular structure such as cotton, painera, cattail, and 
kapok fiber have shown greater oil sorption capacity than other natural organic materials and, recently, vegetable fiber from Calotropis procera [13-16].

The Calotropis procera (Aiton) W. T (CP) is a species originally from Africa and Asia, and therefore considered an invasive species in Brazil [17], and which can currently be found in several regions of the country. However, it is in the Northeast where large populations of the species are established [17-21]. It is a polyvalent plant, which can be used for medicinal, forage, and fuel purposes, wood and fiber production, phytoremediation, synthesis of nanoparticles, and biosorbents [19]. The species has gained prominence due to its good water repellency, high oil selectivity, hollow structure, and a wax layer on the surface, making it a potential raw material for manufacturing high-performance sorbents for removing oil from water [14-17]. Several researchers have published papers attesting to the sorption potential of Calotropis procera fiber oils, such as Thilagavathi et al. (2018) indicating a sorption capacity of $23-40 \mathrm{~g} / \mathrm{g}$, Hilário et al. (2019) of 76-181 g/g, and Anjos et al. (2020) of 92-104 g/g [14-16].

To improve the intrinsic properties or change the characteristics of natural fibers and biomass, these can be subjected to chemical and physical treatments, obtaining materials with new hydrophobic-oleophilic characteristics and high oil sorption capacity [15]. In previous works, Hilário et al. (2019) treated the CP fiber thermally, which showed an increase in oil sorption capacity ranging from approximately 35\% to 137\% [14], and Anjos et al. (2020) using the alkaline treatment with $\mathrm{NaOH}$ in the $\mathrm{CP}$ fiber, showed an increase in the internal diameter and gain in the surface area of the fiber, improving the oil sorption capacity by $68 \%$ when compared to the fresh fiber [15]. However, there are no studies of Calotropis procera fiber treated combining alkaline and thermal treatments for oil removal. Therefore, the present study aims to evaluate the combined $\mathrm{NaOH}$ and thermal treatment in Calotropis procera fiber to improve the oil sorption capacity by modifying the surface and the hollow structure of the fiber. Several parameters such as oil viscosity, fiber/oil contact time, and type of sorption system were the target of this study.

\section{Materials and Methods}

\subsection{Material}

To carry out this study, the fruits of Calotropis procera (Ait.) W. T were collected in the city of Natal, Rio Grande do Norte, Brazil. Paraffin (Density at $25^{\circ} \mathrm{C}, 0.766 \mathrm{~g} / \mathrm{cm}^{3}$ and viscosity at $25^{\circ} \mathrm{C}, 2.25 \mathrm{cP}$ ), crude oil (Density at $25^{\circ} \mathrm{C}, 0.861 \mathrm{~g} / \mathrm{cm}^{3}$ and viscosity at $25^{\circ} \mathrm{C}$, $73.6 \mathrm{cP}$ ), and marine diesel samples (Density at $25^{\circ} \mathrm{C}, 0.825 \mathrm{~g} / \mathrm{cm}^{3}$ and viscosity at $25^{\circ} \mathrm{C}$, $2.38 \mathrm{cP}$ ) used in the sorption tests were supplied by an petroleum company located in Rio Grande do Norte, Brazil. Diesel sample (Density at $25^{\circ} \mathrm{C}, 0.813 \mathrm{~g} / \mathrm{cm}^{3}$ and viscosity at $25^{\circ} \mathrm{C}, 1.95 \mathrm{cP}$ ) was purchased at a fuel station in the city of Natal, Rio Grande do Norte, Brazil. The reagent water used in the tests was obtained through a water ultrapurifier, model Integral 5, Millipore, city of Bedford, MA, USA. Sodium hydroxide PA ACS (NaOH) was purchased from Vetec, Sigma Aldrich, city of Duque de Caxias, Rio de Janeiro, Brazil and was used for alkaline treatment.

\subsection{Combined Treatment of Calotropis Procera}

Previously the fibers of Calotropis procera were removed from the interior of the fruits and manually separated from the seeds and dried at room temperature $\left(25 \pm 1^{\circ} \mathrm{C}\right)$ for $24 \mathrm{~h}$. Then, $2 \mathrm{~g}$ of fiber were placed in a beaker in a $10 \%(v / v) \mathrm{NaOH}$ solution, under stirring for $1 \mathrm{~h}$, according to Anjos et al. (2020) [15]. After treatment with $\mathrm{NaOH}$ the fiber was washed with ultrapure water and taken to a muffle for thermal treatment, as reported by Hilário et al. (2019) [14], modifying the duration of treatment from $1 \mathrm{~h}, 2 \mathrm{~h}$, and $3 \mathrm{~h}$ [22]. After the treatments, the fibers obtained were cooled in a desiccator and stored in zip lock bags.

\subsection{Determination of the Sorption Capacity}

The assessment of oil sorption capacity was performed using the methodology reported by Anjos et al. (2020) [15]. An amount of $0.01 \mathrm{~g}$ of the fiber was immersed in 
the systems $(\mathrm{O}$ and $\mathrm{O} / \mathrm{W})$. Then, the swollen fibers were removed and placed to drain the excess in a stainless steel screen for $5 \mathrm{~min}$. The oil sorption capacity $(\mathrm{g} / \mathrm{g}), \mathrm{S}$, was determined by the gravimetric method and represents the proportion of oil mass to dry fiber mass, calculated by Equation (1):

$$
S=\frac{w_{s 1}-w_{s 0}-w_{s 2}}{w_{s 0}}
$$

where $W_{S 0}$ is the dry fiber mass $(\mathrm{g}), W_{S 1}$ is the swollen fiber mass after oil absorption (g), and $W_{S 2}$ is the mass of water sorbed by the fiber $(\mathrm{g})$. The sorption tests were performed at room temperature $\left(25 \pm 1{ }^{\circ} \mathrm{C}\right)$ and all weighings used an analytical balance $(0.001 \mathrm{~g})$.

\subsection{Design of Experiments}

In order to evaluate the effects of oil viscosity, fiber/oil contact time and the type of sorption system with only oil $(\mathrm{O})$, simulating an oil spill on land, and oil/water $(\mathrm{O} / \mathrm{W})$, simulating an oil spill in water, on the sorption capacity of the CPNaOHT treated fiber, a statistical modeling was performed using the $2^{3}$ factorial design matrix. Establishing these three factors as independent variables: oil viscosity, fiber/oil contact time, and type of sorption system, and as a dependent variable, oil sorption capacity (g oil/g fiber). For each factor, two levels were selected: low $(-1)$ and high $(+1)$, as shown in Table 1 . The tests were performed in duplicates, in a total of 16 experiments.

Table 1. Factors and levels used in experimental design his is a table.

\begin{tabular}{cccc}
\hline \multirow{2}{*}{ Factor } & Symbol & \multicolumn{2}{c}{ Level } \\
\cline { 3 - 4 } & & $\mathbf{- 1}$ & $\mathbf{1}$ \\
\hline Viscosity $(\mathrm{cP})$ & $X_{1}$ & 2.25 & 73.64 \\
Contact time $(\mathrm{h})$ & $X_{2}$ & 1 & 24 \\
System & $X_{3}$ & $\mathrm{O}$ & $\mathrm{O} / \mathrm{W}$ \\
\hline
\end{tabular}

To assess the statistical significance of the models, the analysis of variance (ANOVA) study was performed with $95 \%$ confidence. The calculated $\mathrm{F}$ value $\left(\mathrm{F}_{\text {calc }}\right)$ was compared to the tabulated $\mathrm{F}$ value $\left(\mathrm{F}_{\mathrm{tab}}\right)$ for the $\mathrm{F}$ distribution with the respective degrees of freedom [23]. The polynomial equation of the second-order (Equation (2)) expressed below was used to correlate the oil sorption capacity and the dependent variables. All analysis, calculations, and statistical graphics were obtained with the STATISTICA 7.0 software.

$$
y=b_{0}+\sum_{i=1}^{k} b_{i} x_{i}+\sum_{i=1}^{k} b_{i} x_{i}^{2}+\sum_{i=1}^{k-1} \sum_{j=i+1}^{k} b_{i j} x_{i} x_{j}
$$

where, $I=1-3$ and $j=1-3$.

\subsection{Recycle}

To evaluate the recycling of fiber treated $\mathrm{CPNaOHT}$, sorption with petroleum was performed [14,15]. A total of $10 \mathrm{mg}$ of the fiber was immersed in $5 \mathrm{~mL}$ of petroleum for a time of $60 \mathrm{~min}$ at room temperature $\left(25 \pm 1^{\circ} \mathrm{C}\right)$. After this time of fiber/oil contact, they were compressed with the aid of tweezers, and their recycling capacity was calculated from the ratio of reabsorption mass by the initial sorption mass.

\subsection{Desorption}

After the immersion time of the fiber $\mathrm{CPNaOHT}$ in oil with a contact time of $1 \mathrm{~h}$, drainage was performed on a stainless steel screen for pre-determined times of 1 min; $5 \mathrm{~min}, 10 \mathrm{~min}, 20 \mathrm{~min}, 30 \mathrm{~min}, 40 \mathrm{~min}$, and $60 \mathrm{~min}[24,25]$. The results are presented in terms of oil mass impregnated in the sorbent as a function of time. The experiments were performed in triplicates. 


\subsection{Characterizations}

The surface morphology of the treated fibers was characterized using a scanning electron microscope with field emission (Auriga 40, Zeiss, Oberko-chen, Germany). To obtain the FTIR spectra of the samples, they were recorded on a Frontier spectrometer (Perkin Elmer, Waltham, MA, USA), with a horizontal attenuated total reflectance (ATR) accessory. The surface wettability of fibers was evaluated by measurement of water and diesel contact angles, using a Tensiometer, model K100C (Krüss, Hamburg, Germany). The thermal stability of the $\mathrm{CP}, \mathrm{CPNaOH}$, and $\mathrm{CPNaOHT}$ was evaluated by thermogravimetry analyses-(TG) and Derivative Thermogravimetry using a thermogravimetric analyzer from NETZSCH, TG209F1 Libra (Netsch, Selb, Germany). Approximately $7 \mathrm{mg}$ of sample were used in the TG/DTG analyses, heating rate $10^{\circ} \mathrm{C} \cdot \mathrm{min}^{-1}$, temperature range from 28 to $600{ }^{\circ} \mathrm{C}$, under a dynamic oxygen atmosphere and flowrate of $20 \mathrm{~mL} \cdot \mathrm{min}^{-1}$.

\section{Results and Discussion}

\subsection{Combined Treatment (Alkali + Thermal)}

The Calotropis procera fiber was initially treated with a $\mathrm{NaOH}$ solution $(10 \% v / v)$ for $1 \mathrm{~h} \mathrm{[23],} \mathrm{then} \mathrm{it} \mathrm{was} \mathrm{taken} \mathrm{to} \mathrm{a} \mathrm{muffle} \mathrm{for} \mathrm{thermal} \mathrm{treatment} \mathrm{at} \mathrm{temperatures} \mathrm{of} 150{ }^{\circ} \mathrm{C}$ and $200{ }^{\circ} \mathrm{C}$ with heating rate of $10^{\circ} \mathrm{C} \cdot \mathrm{min}^{-1}$, varying the duration of the heat treatment in $1 \mathrm{~h}$, $2 \mathrm{~h}$, and $3 \mathrm{~h}[14,22]$. To evaluate the effects of the treatments, sorption tests were carried out with only paraffin for the oil only (O) system, with a fiber/oil contact time of $1 \mathrm{~h}$. The tests were carried out in triplicates. Figure 1 shows the sorption capacities for $\mathrm{CP}$ fiber treated at temperatures of $150{ }^{\circ} \mathrm{C}$ and $200{ }^{\circ} \mathrm{C}$ with the duration of treatments from $1 \mathrm{~h}$ to $3 \mathrm{~h}$, for the paraffin tests.

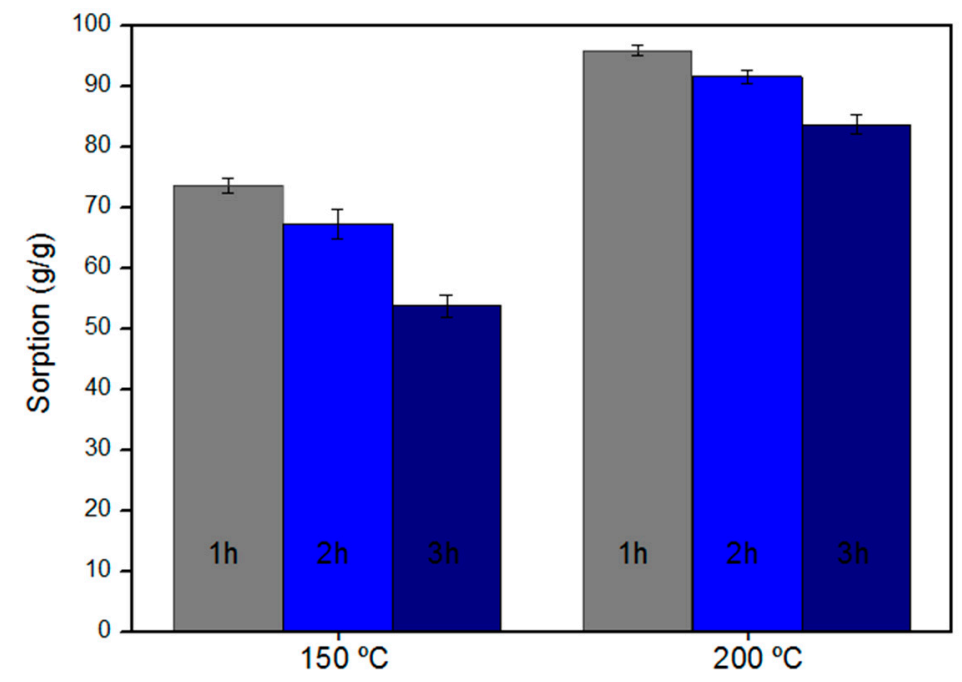

Figure 1. Paraffin sorption capacity of $\mathrm{CP}$ fiber treated at $200{ }^{\circ} \mathrm{C}$ and $150{ }^{\circ} \mathrm{C}$ varying the duration of the heat treatment in $1 \mathrm{~h}, 2 \mathrm{~h}$, and $3 \mathrm{~h}$, for the fiber/oil contact time of $1 \mathrm{~h}$.

It is observed in Figure 1 that increasing the treatment temperature from $150{ }^{\circ} \mathrm{C}$ to $200{ }^{\circ} \mathrm{C}$ increased the paraffin sorption capacity from $30 \%$ to $57 \%$ for all the duration of the heat treatment. Hilário et al. (2019) also observed an increase in the CP sorption capacity with an increase in the treatment temperature from $150{ }^{\circ} \mathrm{C}$ to $200^{\circ} \mathrm{C}$, with the treatment at $200{ }^{\circ} \mathrm{C}$ showing the best $\mathrm{CP}$ sorption capacity for crude oil [14]. For comparison purposes, the paraffin sorption test for $\mathrm{CP}$ in nature was performed, which showed sorption of $53.4 \mathrm{~g} / \mathrm{g}$. Where the fibers treated with $\mathrm{NaOH}$ and thermally at $150{ }^{\circ} \mathrm{C}$ and $200{ }^{\circ} \mathrm{C}$ showed an increase in paraffin sorption capacity from $52 \%$ to $74 \%$ compared to the untreated fiber.

The effect of the duration of the heat treatment on the oil sorption capacity of the $\mathrm{CP}$ fiber was also evaluated (Figure 1). Observing the increase in the duration of heat treatment from $1 \mathrm{~h}$ to $3 \mathrm{~h}$, the sorption capacity of the treated fibers decreased, with losses 
ranging from 5 to $34 \%$. It was also observed that the fibers after the treatment duration time of $2 \mathrm{~h}$ and $3 \mathrm{~h}$ proved to be brittle, possibly due to fiber degradation with an increase in the treatment duration time. This may have led to a decrease in the paraffin sorption capacity. Husseien et al. (2009) observed that increasing the duration of the heat treatment from $1 \mathrm{~h}$ to $3 \mathrm{~h}$ at $200{ }^{\circ} \mathrm{C}$ increased the sorption capacity of the corn stem for the diesel and dye studied [22]. In Figure 2, it is possible to observe the visual aspects of the fibers treated at $150{ }^{\circ} \mathrm{C}$ and $200^{\circ} \mathrm{C}$, for the duration of heat treatment of $1 \mathrm{~h}, 2 \mathrm{~h}$, and $3 \mathrm{~h}$.

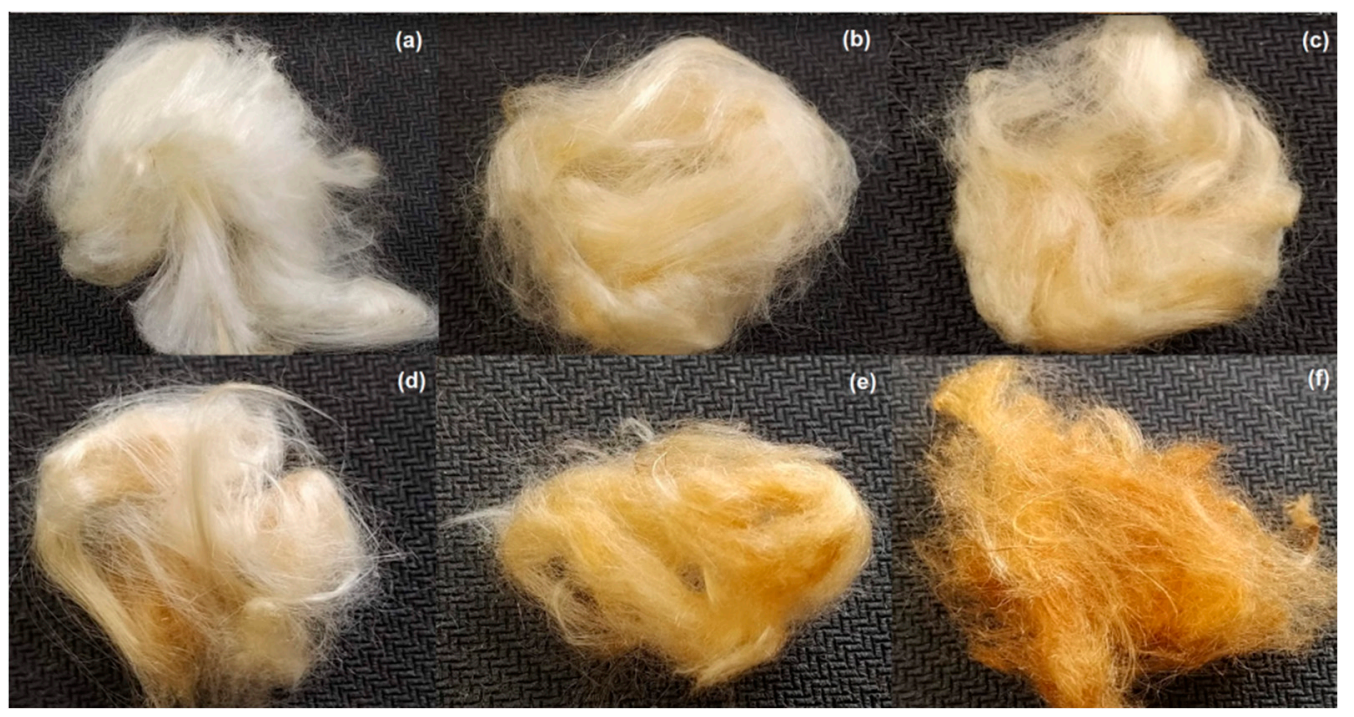

Figure 2. Image of fibers treated whit $\mathrm{NaOH}$ and at $150{ }^{\circ} \mathrm{C}$ for (a) $1 \mathrm{~h},(\mathbf{b}) 2 \mathrm{~h},(\mathbf{c}) 3 \mathrm{~h}$ and $200{ }^{\circ} \mathrm{C}$ for (d) $1 \mathrm{~h},(\mathbf{e}) 2 \mathrm{~h},(\mathbf{f}) 3 \mathrm{~h}$.

The fiber treated with $\mathrm{NaOH}(10 \% v / v)$ and thermally at $200^{\circ} \mathrm{C}$ for $1 \mathrm{~h}$ had the highest sorption capacity of $95.94 \pm 0.88 \mathrm{~g} / \mathrm{g}$ (Figure 1), being chosen for the other tests of sorption and characterization. The treated fiber chosen was named $\mathrm{CPNaOHT}$.

\subsection{Design of Experiments}

The levels of significant factors and effects of interactions between the factors that were analyzed by factorial design $2^{3}$. The three factors: viscosity $(\mathrm{cP})$ of the oil, fiber/oil contact time (h), and the type of oil-only sorption system $(\mathrm{O})$, and oil and water $(\mathrm{O} / \mathrm{W})$ were selected according to the literature $[14,15,24-28]$ and planned according to the matrix described in Table 2. For modeling purposes, the independent variables (factors) were scaled for coded variables (Table 2), and the sorption capacity of the materials for oils was named $S_{1}(\mathrm{~g} / \mathrm{g})$.

Table 2. Experimental results and calculated results by the models his is a table.

\begin{tabular}{|c|c|c|c|c|}
\hline$X_{1}$ & $X_{2}$ & $X_{3}$ & Experimental (g/g) & Calculated (g/g) \\
\hline-1 & -1 & -1 & 95.45 & \multirow[b]{2}{*}{95.44} \\
\hline-1 & -1 & -1 & 95.42 & \\
\hline 1 & -1 & -1 & 92.88 & \multirow[b]{2}{*}{92.66} \\
\hline 1 & -1 & -1 & 92.44 & \\
\hline-1 & 1 & -1 & 88.61 & \multirow{2}{*}{88.32} \\
\hline-1 & 1 & -1 & 88.04 & \\
\hline 1 & 1 & -1 & 121.40 & \multirow{2}{*}{120.91} \\
\hline 1 & 1 & -1 & 120.41 & \\
\hline-1 & -1 & 1 & 98.87 & \multirow{3}{*}{98.86} \\
\hline-1 & -1 & 1 & 98.85 & \\
\hline 1 & -1 & 1 & 123.36 & \\
\hline 1 & -1 & 1 & 124.31 & 123.84 \\
\hline-1 & 1 & 1 & 84.51 & \multirow[b]{2}{*}{84.31} \\
\hline-1 & 1 & 1 & 84.10 & \\
\hline 1 & 1 & 1 & 190.14 & \multirow[b]{2}{*}{190.32} \\
\hline 1 & 1 & 1 & 190.50 & \\
\hline
\end{tabular}


To assess the statistical significance of the model, the analysis of variance (ANOVA) study was performed at $95 \%$ confidence. According to the analysis of variance performed for the results obtained, it was verified that the model is significant with a correlation coefficient of $\mathrm{R}^{2}$ de 0.99992 , R-adj de 0.99985 e $p<0.05$ (Table 3). The value of the $\mathrm{F}_{\text {cal }}$ test was compared to the value of the $\mathrm{F}_{\text {tab }}$ test for the distribution $\mathrm{F}$ with the respective degrees of freedom and the value of $\mathrm{F}_{\mathrm{cal}}$ regression was 4113 times greater than the $\mathrm{F}_{\mathrm{tab}}$, at a confidence level of $95 \%$. These facts show that the above model explains $99.9 \%$ of the variation of the experimental data indicating that the model is meaningful and predictive, so the model can be applied to predict the oil sorption capacity within the ranges discussed in this work [23].

Table 3. Analysis of Variance (ANOVA).

\begin{tabular}{cccccc}
\hline Source & Sum of Squares & DF1 & $\begin{array}{c}\text { Mean } \\
\text { Squares }\end{array}$ & F & $p$ \\
\hline (1) Viscosity (cP) & 6463.76 & 1 & 6463.758 & $38,302.33$ & $5.20 \times 10^{-16}$ \\
(2) Contact time (h) & 1334.62 & 1 & 1334.624 & 7908.59 & $2.85 \times 10^{-13}$ \\
(3) System & 2499.75 & 1 & 2499.750 & $14,812.78$ & $2.32 \times 10^{-14}$ \\
1 by 2 & 3386.95 & 1 & 3386.949 & $20,070.07$ & $6.89 \times 10^{-15}$ \\
1 by 3 & 2559.60 & 1 & 2559.601 & $15,167.44$ & $2.11 \times 10^{-14}$ \\
2 by 3 & 237.08 & 1 & 237.083 & 1404.88 & $2.82 \times 10^{-10}$ \\
$1 * 2 * 3$ & 521.78 & 1 & 521.780 & 3091.91 & $1.21 \times 10^{-11}$ \\
\hline Regression & $17,003.54$ & 7 & 2429.078 & & Significant and predictive \\
Residuals & 1.35 & 8 & 0.168756 & & $\mathrm{~F}_{\text {calc }} / \mathrm{F}_{\text {tab }}=4112.572$ \\
Total & $17,004.89$ & 15 & $\mathrm{~F}_{\text {calc }}=14394$ & \\
\hline R-sqr $=0.99992$ & R-adj $=0.99985$ & & &
\end{tabular}

1-DF-Degree of freedom; R-sqr-Correlation coefficient; R-sqr-R adjusted; $\mathrm{F}_{\text {tab }}=3.5$.

Based on the experimental design shown in Table 3, the regression model was constructed to describe the functional relationship between the variables (independent variables) and $\mathrm{CPNaOHT}$ sorption capacity (response). The polynomial regression model of second-order in terms of coded variables $\left(X_{1}, X_{2}\right.$, and $\left.X_{3}\right)$ that predict the sorption-city cover $\left(S_{1}\right)$ of $\mathrm{CPNaOHT}$ can be written by Equation (3), considering the significant factors $(p<0.05)$ and their interactions. The equation was obtained using Statistica software version 7.0.

$S_{1}=111.8306+20.0994 X_{1}+9.1331 X_{2}+12.4994 X_{3}+9.1331 X_{2}+14.5494 X_{1} X_{2}+12.6481 X_{1} X_{3}+3.8494 X_{2} X_{3}+5.7106 X_{1} X_{2} X_{3}$

The model fit can be observed in Figure 3a through the relation of experimental and predicted values for $\mathrm{CPNaOHT}$ oil sorption. For model validation purposes, a new oil with a viscosity of $2.38 \mathrm{cP}$ (Marine diesel) was chosen to perform a sorption test at the fiber/oil contact time of $1 \mathrm{~h}$, using the sorption system with only oil (O). The experiments were carried out in triplicate and the mean sorption capacity determined experimentally was $94.65 \pm 0.22 \mathrm{~g} / \mathrm{g}$. The value calculated by the model was $95.40 \mathrm{~g} / \mathrm{g}$, with a low absolute error of 0.75 . All these statistical estimators reveal that the oil sorption model $\left(S_{1}\right)$ is statistically validated to predict the response in the experiment region. 

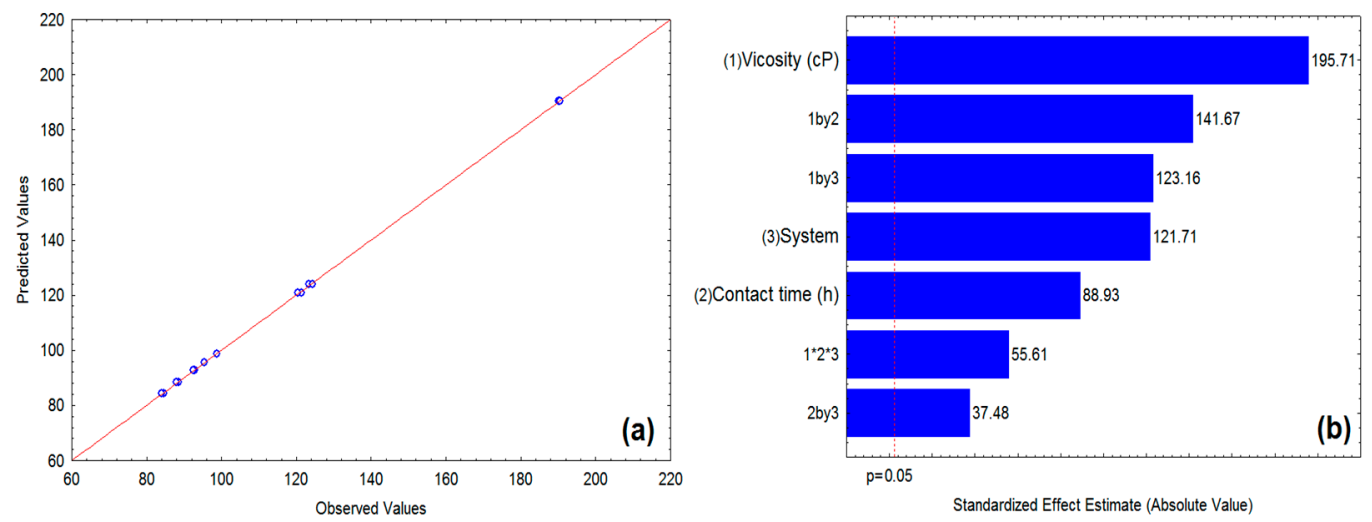

Figure 3. Relationship between experimental and predicted values for oil sorption (a) and Pareto diagram (b).

\subsection{Effect of Variables on $\mathrm{CPNaOHT}$ Sorption Capacity}

Whereas the model has been adjusted (meaningful and predictive), the effects of variables and interactions between them over the $\mathrm{CPNaOHT}$ sorption capacity were evaluated based on the Pareto diagram (Figure 3b), to a confidence level of $95 \%$. According to the Pareto diagram (Figure $3 b$ ), all effects were significant $(p<0.05)$, alone or combined for $\mathrm{CPNaOHT}$ sorption capacity. Evaluating the effect of isolated variables, it is observed that the viscosity showed a greater influence on the sorption process. The oil viscosity is a parameter of great importance in the sorption process as reduced oil viscosity reduces sorption into the pores and vessels capillaries of materials, and more viscous oils have higher sorption due to adhesion to surfaces of materials and in pores [24-28]. Wei et al. (2003) showed in their experiments that increasing the viscosity from $18.7 \mathrm{cP}$ to $54.8 \mathrm{cP}$ contributes significantly to the increase in the sorption capacity of polypropylene [24]. However, it is noted that even for low viscosity oils $(\mathrm{cP}=2.25)$, fiber $\mathrm{CPNaOHT}$ has a high average sorption capacity of $98.86 \mathrm{~g} / \mathrm{g}$, demonstrating the potential of CPNaOHT for removal/sorption of oils with viscosity varying from 2.25 to $73.6 \mathrm{cP}$.

The type of sorption system $(\mathrm{O}$ and $\mathrm{O} / \mathrm{W})$ had a significant influence on the sorption capacity CPNaOHT $(p<0.05)$, the sorption system $\mathrm{O} / \mathrm{W}$ which had the highest oil removal capacity. This is possibly due to the difference in polarity between oil and water, causing the oil to be pushed into the fiber lumens by the repulsion forces added to the capillary force.

The contact time between fiber and oil in the sorption process showed a directly proportional effect (Figure 3b), this implies that the higher the CPNaOHT contact time with the oil, the greater the sorption capacity. The increase in contact time led to decreased sorption of paraffin, possibly by lower viscosity paraffin, having full capacity in just one hour. However, the oil has a lower sorption rate within the pores and capillaries in the $1 \mathrm{~h}$ contact time, reaching full capacity within $24 \mathrm{~h}$.

In Figure 4, it is possible to observe the effects of the independent variables (viscosity, system and contact time) in relation to the average values of the oil sorption capacity within the $95 \%$ confidence interval, for the set of experiments performed according to with the experimental design (Table 2). It is observed that all variables showed an increase in the sorption capacity with the increment from -1 to 1 , with the sorption condition being for the oil with higher viscosity $(73.6 \mathrm{cP})$, the $\mathrm{O} / \mathrm{W}$ system and the longest oil contact time/fiber $(24 \mathrm{~h})$, which had the best oil removal capacity. The results show that $\mathrm{CPNaOHT}$ fiber has greater potential for sorption and use in case of oil spills in aquatic environments than in terrestrial environments (without the presence of water), reaching a removal of $84.31 \mathrm{~g} / \mathrm{g}$ to $190.32 \mathrm{~g} / \mathrm{g}$ of oil in water. 

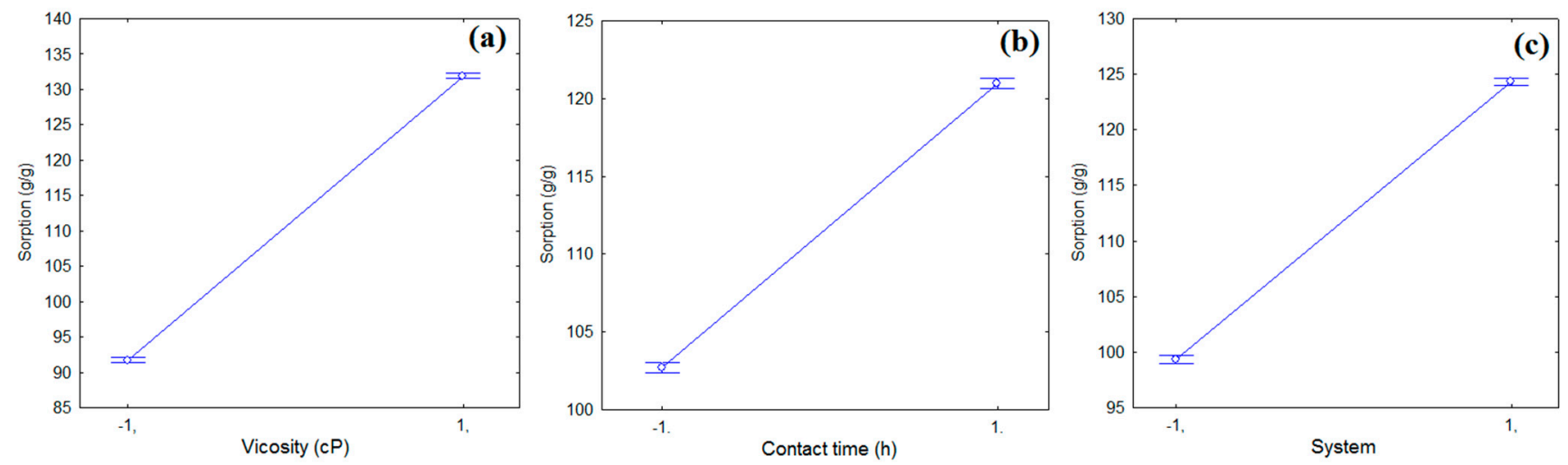

Figure 4. Effects of the independent variables: (a) viscosity, (b) contact time, and (c) sorption system, in relation to the mean values of the oil sorption capacity (95\% confidence interval).

\subsection{Recycle Desorption}

To assess the ability of recycling/reuse $\mathrm{CPNaOHT}$ has performed a sorption system with only oil (O) to the time of contact fiber/oil $60 \mathrm{~min}$, followed by simple compression and weighed again for 5 cycles. The reuse of the fibrous oil sorbent in terms of sorption capacity during five cycles of sorption/desorption is shown in Figure 5a. It is observed the decrease of sorption capacity for each $90 \%$ duty cycle, $82 \%, 71 \%, 62 \%$, and $49 \%$, but the average capacity of resorption of the fibers after 5 cycles was higher than $70 \%$ oil as compared to the sorption initial, demonstrating that $\mathrm{CPNaOHT}$ fiber still has the potential for reuse even after sorption 5 consecutive uses.
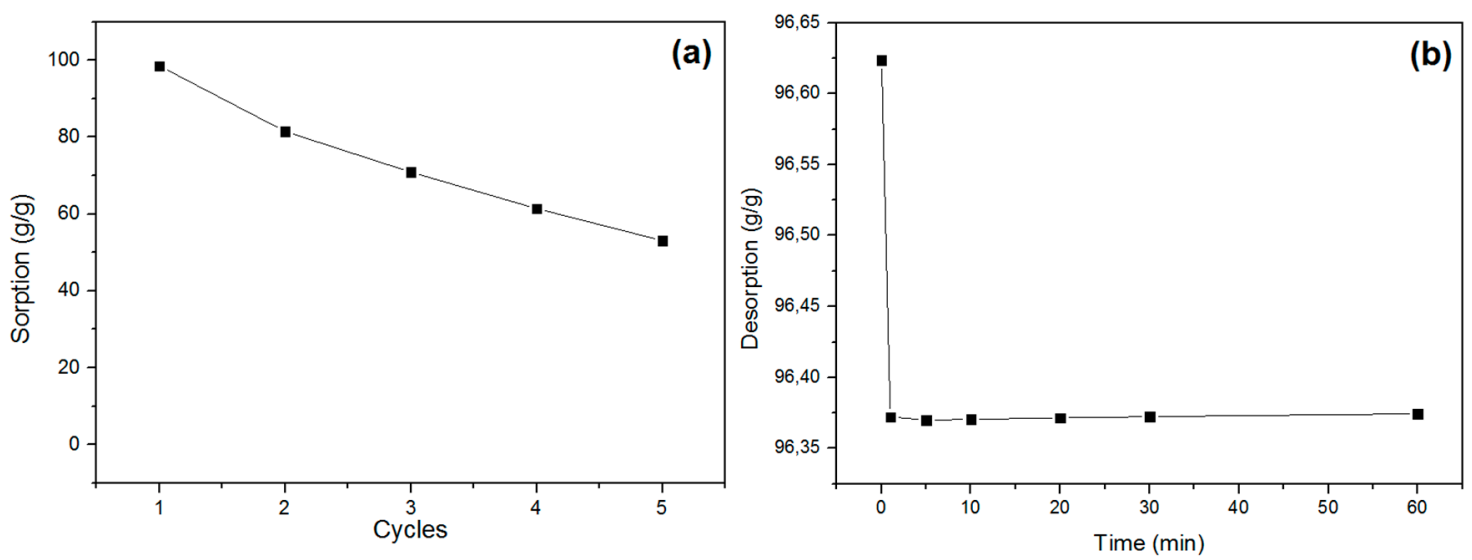

Figure 5. Recycling (a) and desorption (b) tests for CPNaOHT using petroleum.

The study of liquid loss from sorbents over time is of paramount importance in actual application $[24,25]$. Figure $5 \mathrm{~b}$ shows the desorption of petroleum by $\mathrm{CPNaOHT}$ in times from 1 to $60 \mathrm{~min}$, where a general trend of net loss divided into two stages is observed. Initially, the liquid loss rate is higher and the holding capacity drops. A transition zone, where desorption virtually ends, is observed, reaching a steady-state condition under which no liquid is lost due to dripping (Figure $5 b$ ). The maximum loss of oil mass by desorption of $\mathrm{CPNaOHT}$ was approximately $0.25 \mathrm{~g}$, after $60 \mathrm{~min}$ of drainage.

\subsection{Short Time Sorption Tests}

In real cases of oil spills, the faster the process of sorption occurs, the smaller the environmental impacts on the marine environment or land. Anjos et al. (2021) evaluated the concentrations of BTEX (benzene, toluene, ethylbenzene, and xylenes) in the soluble fraction of oil, simulating a spill by varying the contact time of the oil in seawater from 1 to $24 \mathrm{~h}$, where the concentrations of benzene, carcinogenic compound, and mutagenic 
exceeds the most restrictive value by CONAMA $(51 \mu \mathrm{g} / \mathrm{L})$ for saline waters where there is fishing or cultivation of organisms, for intensive consumption purposes (BRASIL, 2005), in just $1 \mathrm{~h}[28,29]$. With $24 \mathrm{~h}$ of oil spill into seawater, the average concentrations of benzene, toluene, ethylbenzene, and xylenes were $1409 \mu \mathrm{g} / \mathrm{L}, 1279 \mu \mathrm{g} / \mathrm{L}, 67 \mu \mathrm{g} / \mathrm{L}$, and $357 \mu \mathrm{g} / \mathrm{L}$, respectively, showing the importance of the removal of this oil in a short period. To evaluate the sorption capacity of $\mathrm{CPNaOHT}$ in shorter times, sorption tests were carried out for short times of 5, 20, $40 \mathrm{~min}$ for the two sorption systems with only oil and oil/water, for petroleum and paraffin [28].

Figure 6 shows the average sorption capacity for short time tests $(5,20$, and $40 \mathrm{~min})$ for systems with only oil and oil/water. Paraffin showed a characteristic of increasing sorption capacity with increasing time from 5 to $40 \mathrm{~min}$, for both sorption systems. Petroleum presented a stable sorption capacity already at $5 \mathrm{~min}$, remaining up to $40 \mathrm{~min}$, for the oil-only system, and in the oil/water system, it presented an increase in sorption capacity over time. The short sorption time tests showed that the $\mathrm{CPNaOHT}$ fiber showed good oil removal capacity, ranging from $74.1 \mathrm{~g} / \mathrm{g}$ to $102.9 \mathrm{~g} / \mathrm{g}$, which can be a good alternative in emergency cases of oil containment.
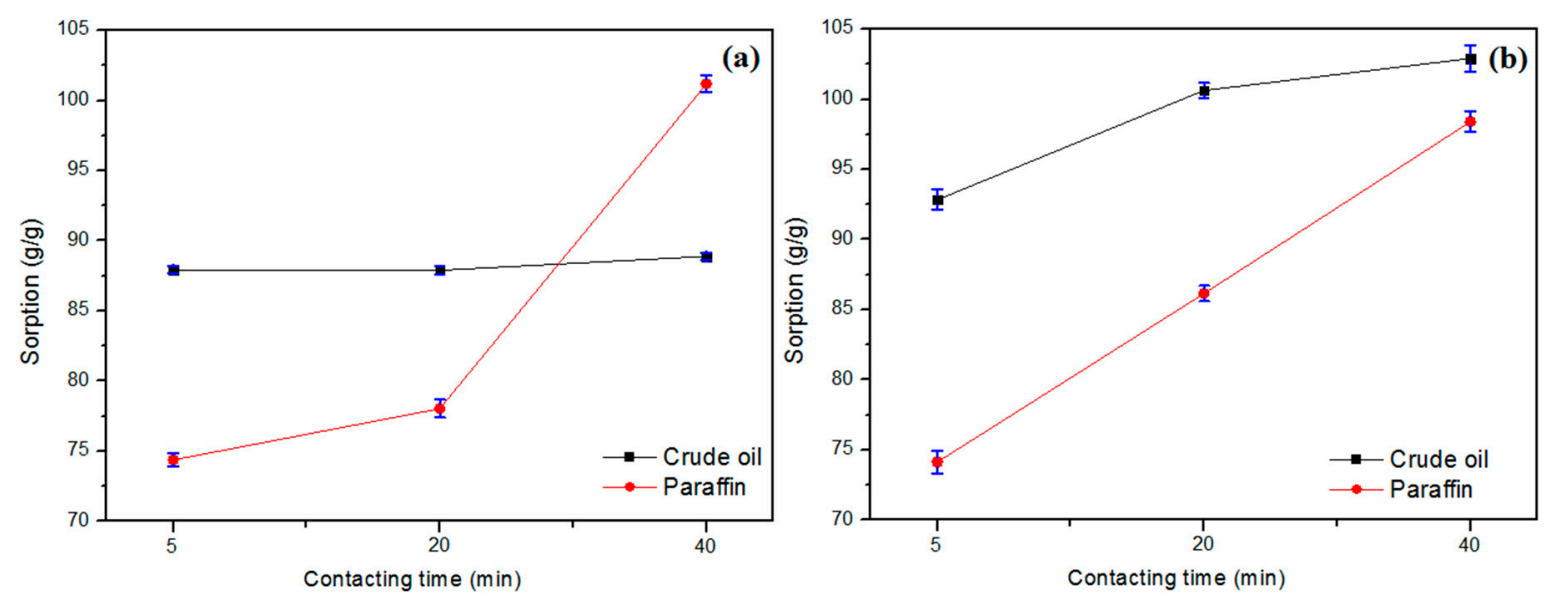

Figure 6. Short-time sorption tests for system (a) oil only and (b) oil/water, for petroleum and paraffin.

The data from the present study indicate that the fiber treated by combining $\mathrm{NaOH}$ and heat treatment (CPNaOHT) showed an increase in petroleum sorption capacity of $150 \%$ and $74 \%$ for paraffin when compared to CP fiber in nature. The treated fiber had a higher sorption capacity than $\mathrm{CPT} 150$ (thermal treatment at $150{ }^{\circ} \mathrm{C}$ ), $\mathrm{CPT} 200$ (thermal treatment at $200{ }^{\circ} \mathrm{C}$ ), $\mathrm{CPNaOH}$ (treated with $\mathrm{NaOH}$ ), $\mathrm{CPNaClO}_{2}$ (treated with $\mathrm{NaClO}_{2}$ ), and CPHT (treated with hydrothermal) fibers, previously studied by Hilário et al. (2019) and Anjos et al. (2020), suggesting that the new treatment process significantly improved the sorption capacity of the fibers and could be used as an efficient sorbent for the removal of spilled oil in both aquatic and terrestrial environments [14,15]. Figure 7 represents the sorption process of $\mathrm{CPNaOHT}$ fiber in the $\mathrm{O} / \mathrm{W}$ system, using diesel oil (Density at $25^{\circ} \mathrm{C}$, $0.813 \mathrm{~g} / \mathrm{cm}^{3}$ and viscosity at $25^{\circ} \mathrm{C}, 1.95 \mathrm{cP}$ ), also showing that the fiber has good sorption capacity for diesel (Figure 7b-d) and good buoyancy in water (Figure 7a) (A video file of the $\mathrm{CPNaOHT}$ fiber sorption test with diesel oil was provided in Supplementary Materials). 


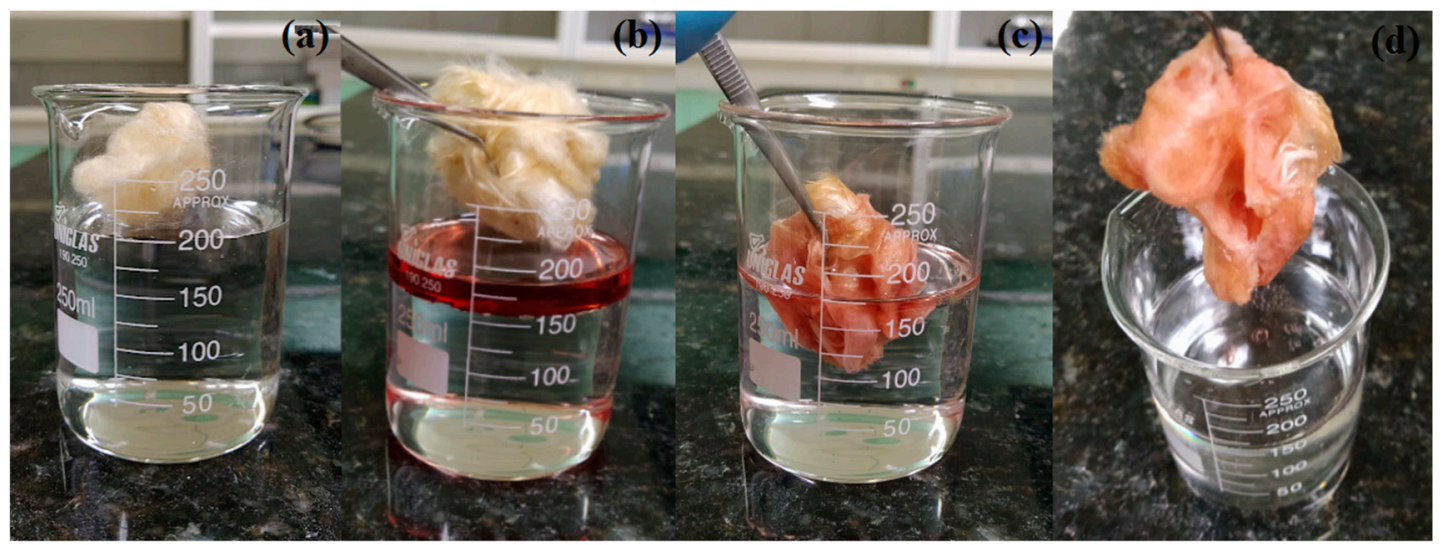

Figure 7. Digital images of the water sorption test (a) and removal of diesel oil in water using CPNaOHT (b-d), (b) a volume of oil was added in distilled water forming a supernatant layer, (c) rapid oil sorption diesel by CPNaOHT, and (d) clean water after diesel sorption.

\subsection{Characterizations}

The morphology of CPNaOHT obtained was characterized by SEM-FEG and the micrographs are shown in Figure $8 \mathrm{a}, \mathrm{c}$. The $\mathrm{CP}$ and $\mathrm{CPNaOH}$ fibers previously studied by Hilário et al. (2019) and Anjos et al. (2020), respectively, presented a cylindrical shape with large lumens, thin and smooth walls $[14,15]$. After $\mathrm{CP}$ was combined with $\mathrm{NaOH}$ and thermal treatment at $200{ }^{\circ} \mathrm{C}$ for $1 \mathrm{~h}$, the fiber surface became rough (Figure 8b). Previous treatment with $\mathrm{NaOH}$ may have left the fibril structure more exposed and susceptible to the action of heat treatment, thus generating surface roughness [30]. It was also possible to observe that the internal diameter increase after CPNaOHT treatment was $80 \%$ $(42.99 \pm 3.98 \mu \mathrm{m}, n=10)$, compared to CP fiber without treatment. The CP fiber treated only with $\mathrm{NaOH}$ showed an internal diameter increase of $57 \%(37.47 \pm 3.80 \mu \mathrm{m})$, when compared to the CP fiber $(23.84 \pm 4.44 \mu \mathrm{m})$ [26]. Such a hollow tubular structure combined with roughness increases the $\mathrm{CPNaOHT}$ sorption potential of various oils.

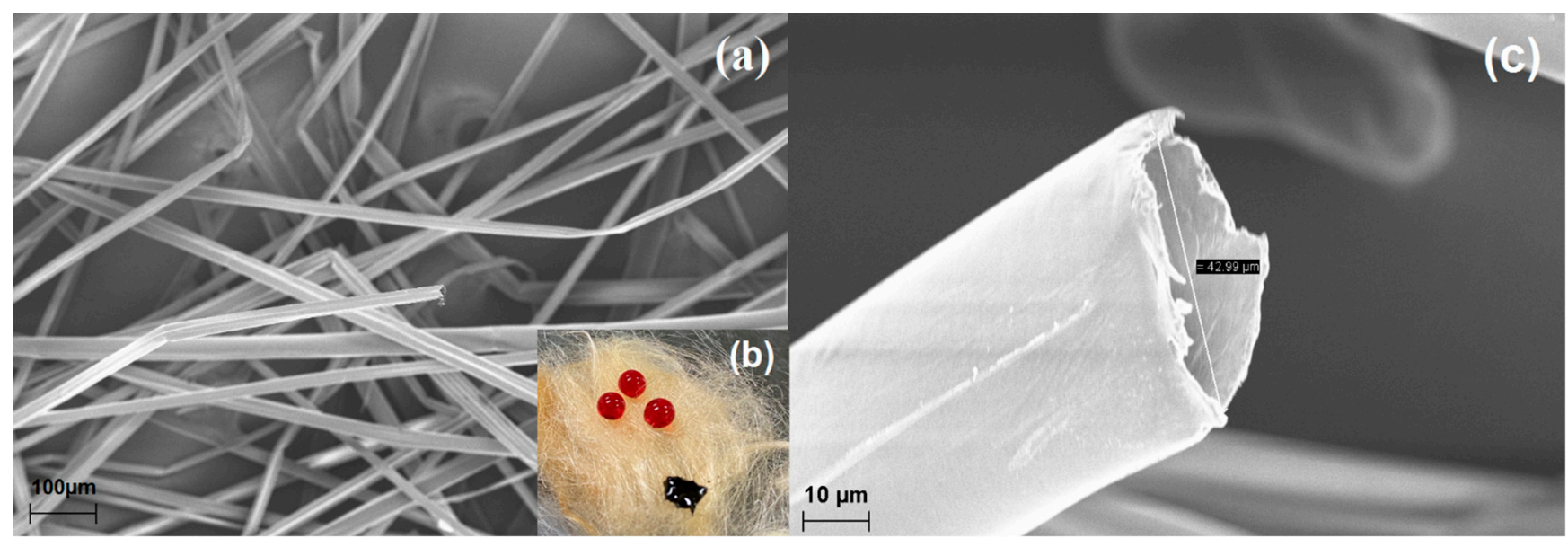

Figure 8. Micrograph obtained by the (a) SEM-FEG 100×, (b) digital image of the wettability test, and (c) SEM-FEG 1000 $\times$ in $\mathrm{CPNaOHT}$.

To verify the hydrophobic and oleophilic properties of the CPNaOHT fiber, the wettability test in water and oil on the fiber surface was performed, as shown in Figure 8b, where the hydrophobicity and olefinicity are visible on the CPNaOHT surface. The contact angle $(\theta)$ for $\mathrm{CPNaOHT}$ water was $101 \pm 2^{\circ}$ (Figure $9 \mathrm{a}, \mathrm{b}$ ), showing that the material is hydrophobic, that is, oil is preferred over water. Comparing the contact angle of $\mathrm{CPNaOHT}$ with fiber treated only with $\mathrm{NaOH}\left(\mathrm{CPNaOH} \theta=114^{\circ}\right.$ ) (Anjos et al., 2020) and $\mathrm{CP}$ fiber in 
natura $\left(\theta=128^{\circ}\right)$ (Hilário et al., 2019), it was is possible to observe that the surface of the material after the combined treatment was modified, sorbing more water [14,15]. The use of plant materials as sorbents in an aqueous medium generally present high water sorption (Annunciation et al., 2005), however in the present study the amount of water sorbed in relation to oils was negligible (Figure 9c), ranging from 0.28 to $0.70 \mathrm{~g} / \mathrm{g}$ in the range of 5 to $60 \mathrm{~min}$ [11]. It is also observed that water sorption increased with time. The CPNaOHT fiber sorbed more water when compared to the CP fiber in nature and the fiber treated only with $\mathrm{NaOH}(\mathrm{CPNaOH})$, possibly by removing the wax from the $\mathrm{CP}$ surface by the combined treatment. The results of the contact angle and sorption for water suggest the hydrophobic character of the $\mathrm{CPNaOHT}$ fiber.
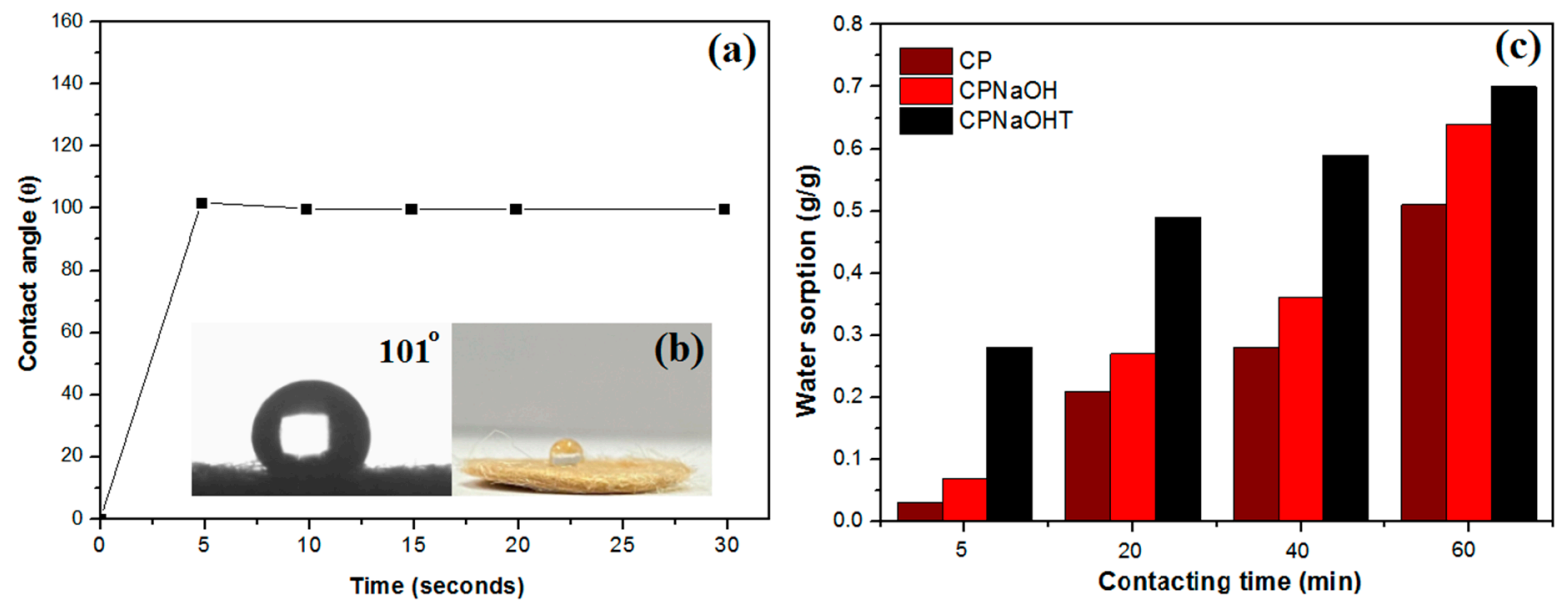

Figure 9. (a) $\mathrm{CPNaOHT}$ water contact angle test. (b) Digital image of tablet $\mathrm{CPNaOHT}$ used to measure the contact angle and (c) $\mathrm{CP}, \mathrm{CPNaOH}$, and $\mathrm{CPNaOHT}$ water sorption varying fiber/oil contact time from 5 to $60 \mathrm{~min}$.

Figure 10 shows the FTIR spectra of the CPNaOHT, CP, and CPNaOH fiber [14,15]. When comparing the spectra of $\mathrm{CP}$ in nature and treated only with $\mathrm{NaOH}(\mathrm{CPNaOH})$ there was no significant change in the spectra, however in the region of the functional groups' $\mathrm{CH}\left(2920 \mathrm{~cm}^{-1}\right), \mathrm{C}=\mathrm{O}\left(1734,1368\right.$, and $\left.1244 \mathrm{~cm}^{-1}\right)$, and $\mathrm{CO}\left(1032 \mathrm{~cm}^{-1}\right)$ [14], there was a decrease in intensities possibly associated with removal of wax on the fiber surface with $\mathrm{NaOH}$ treatment [15]. In CPNaOHT, it was noted attenuation of peaks close to lignin (1505 and $1597 \mathrm{~cm}^{-1}$ ) and hemicellulose (1734 and $1244 \mathrm{~cm}^{-1}$ ) [15]. The peak of $897 \mathrm{~cm}^{-1}$ was also attenuated, possibly related to the removal of hemicellulose with the combined alkaline plus thermal treatment. Also, there was a minimization of bands in the region between 1602 and $1508 \mathrm{~cm}^{-1}$.

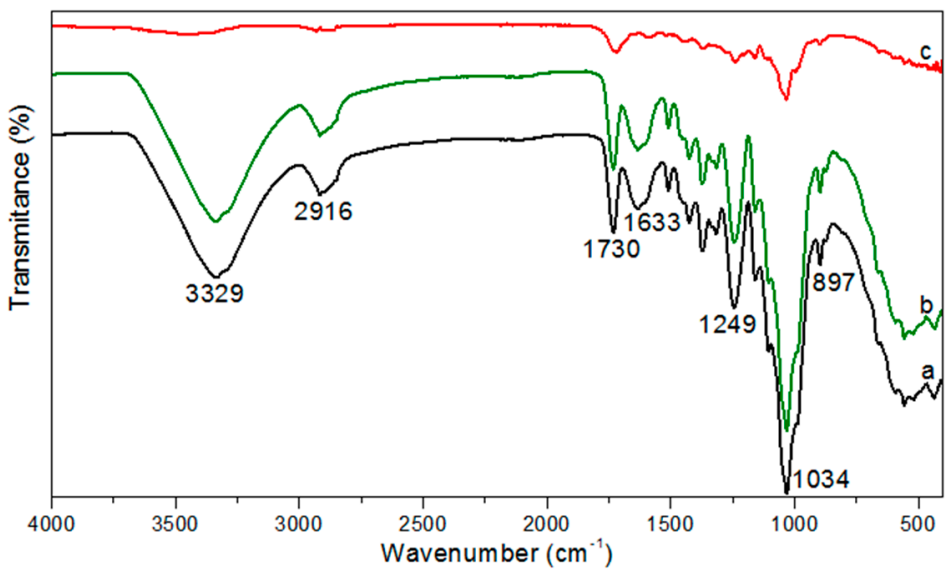

Figure 10. FTIR spectra (a) $\mathrm{CP}$; (b) $\mathrm{CPNaOH}$; (c) $\mathrm{CPNaOHT}$. 
When comparing the $\mathrm{CP}$ fiber spectra with $\mathrm{CPNaOHT}$, the heat-treated sample showed the decreased intensity of functional groups, including $\mathrm{CH}\left(2915 \mathrm{~cm}^{-1}\right), \mathrm{C}=\mathrm{O}(1734,1368$ and $\left.1244 \mathrm{~cm}^{-1}\right)$, and $\mathrm{CO}\left(1032 \mathrm{~cm}^{-1}\right)$ [14]. Also being noted, decrease of peaks close to lignin (1505 and $\left.1597 \mathrm{~cm}^{-1}\right)$ and hemicellulose $\left(1737\right.$ and $\left.1248 \mathrm{~cm}^{-1}\right)$ [15,31].

To evaluate the thermal stability of CPNaOHT, thermogravimetric studies (TG/DTG) were performed. Figure 11 shows the TG/DTG curves for CP, CPNaOH, and CPNaOHT [25].
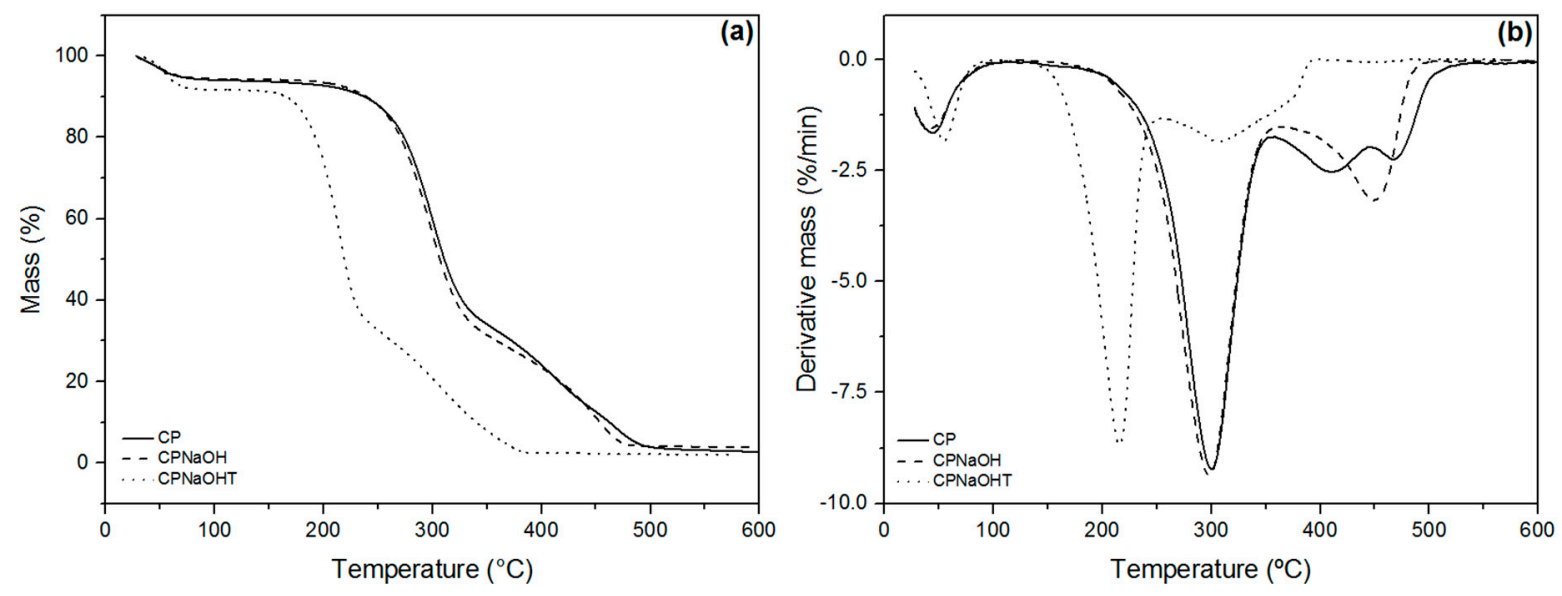

Figure 11. Thermogravimetry (a) and Derivative Thermogravimetry (b) curves of $\mathrm{CP}, \mathrm{CPNaOH}$, and CPNaOHT.

In Figure 11 we can see an initial mass loss for $\mathrm{CP}, \mathrm{CPNaOH}$, and $\mathrm{CPNaOHT}$ that occurred below $100{ }^{\circ} \mathrm{C}$ due to the release of weakly bound water molecules. It is observed that CPNaOHT presented greater loss of weakly bound water when compared to CP and $\mathrm{CPNaOH}$ (Figure 11). The second event (Figure 10a) shows a sudden mass loss, referring to hemicellulose degradation [31], similar for $\mathrm{CP}, \mathrm{CPNaOH}$, and CPNaOHT. The DTG results indicate a significant decrease in the decomposition temperature of CPNaOHT fiber hemicellulose. This is possibly due to exposure of fibrils to heat treatment after pretreatment with $\mathrm{NaOH}$. The same happened in the region between 250 and $400{ }^{\circ} \mathrm{C}$ with the cellulose and/or lignin degradation peaks. For $\mathrm{CPNaOH}$ between 350 and $500{ }^{\circ} \mathrm{C}$, a single peak was observed, which can be attributed to lignin degradation by the alkali treatment. The fiber treated by combining $\mathrm{NaOH}$ and thermal treatment showed a reduction in degradation temperature.

\section{Conclusions}

The combined treatment (alkaline and thermal) in Calotropis procera fiber significantly improved the oil sorption capacity. It was found that the treatment significantly increased the hollow space of the fiber, there was a roughness gain on the fiber surface and a contact angle with water of $101 \pm 2^{\circ}$ and $0^{\circ}$ for oil, showing potential for hydrocarbon sorption, hydrophobicity, and great affinity for oil. Oil sorption capacities ranged from 84.31 to $190.32 \mathrm{~g} / \mathrm{g}$ of paraffin and/or petroleum. The recycle test demonstrates a drop in the original oil sorption capacity, reaching recovery up to $70 \%$ after five reuse cycles. Through experimental planning, it was possible to evaluate the effect of viscosity, fiber/oil contact time, and type of sorption system on the sorption capacity of $\mathrm{CPNaOHT}$, revealing that fiber has greater potential for sorption and use in case of oil spills in aquatic environments than in terrestrial environments (without the presence of water). Short-term trials demonstrated that $\mathrm{CPNaOHT}$ fiber has the potential for use in emergency cases. In conclusion, the treated fiber has excellent environmental compatibility and reuse, and it can be used as a sorbent for oil removal in spills of oil and its derivatives. Further investigations of CP and $\mathrm{CPNaOHT}$ fibers are planned and large-scale fabrication will be explored.

Supplementary Materials: The following are available online at https:/ /www.mdpi.com/article/10 .3390 / polym13193285/s1, Real-time video showing oil sorption by CPNaOHT fiber (treated with 
$\mathrm{NaOH}+$ thermal) to show sorbent performance is available as background information. The method used to assess the sorption capacity of crude oil and paraffin is exactly the same as shown in the video (oil/water sorption system), with the change being just the oil type for better visualization of the sorption process.

Author Contributions: All authors worked on this research. Conceptualization, R.B.d.A.; L.S.H.; A.S.D.d.A.; E.C.T.d.A.C.; T.M.P.F. methodology, R.B.d.A.; L.S.H.; A.S.D.d.A.; formal analysis, R.B.d.A.; L.S.H.; A.S.D.d.A.; E.C.T.d.A.C.; T.M.P.F.; writing-preparation of the original draft, R.B.d.A.; L.S.H.; A.S.D.d.A.; E.C.T.d.A.C.; T.M.P.F.; writing-review and editing, A.D.G., D.R.d.S., supervision, D.R.d.S project administration, A.D.G., D.R.d.S. All authors have read and agreed to the published version of the manuscript.

Funding: This research received no external funding.

Institutional Review Board Statement: Not applicable.

Informed Consent Statement: Not applicable.

Data Availability Statement: Not applicable.

Acknowledgments: The authors would like to thank the Nucleus of Primary Processing and Reuse of Produced Water and Waste of the Federal University of Rio Grande do Norte for the financial support.

Conflicts of Interest: The authors declare no conflict of interest.

\section{References}

1. Wahi, R.; Chuah, L.A.; Choong, T.S.Y.; Ngaini, Z.; Nourouzi, M.M. Oil removal from aqueous state by natural fibrous sorbent: An overview. Sep. Purif. Technol. 2013, 113, 51-63. [CrossRef]

2. Paul, J.H.; Hollander, D.; Coble, V.; Daly, K.L.; Murasko, S.; English, D.; Basso, J.; Delaney, J.; McDaniel, L.; Kovach, C.W. Toxicity and mutagenicity of gulf of Mexico waters during and after the deepwater horizon oil spill, Environ. Sci. Technol. 2013, 47, 9651-9659. [CrossRef] [PubMed]

3. Instituto Brasileiro do Meio Ambiente e dos Recursos Naturais Renováveis. Localidades Afetadas. 2019. Available online: http:/ / www.ibama.gov.br/phocadownload/emergenciasambientais/2019/manchasdeoleo/2019-11-24_LOCALIDADES_ AFETADAS.pdf (accessed on 25 January 2021).

4. Zacharias, D.C.; Gama, C.M.; Fornaro, A. Mysterious oil spill on Brazilian coast: Analysis and estimates. Mar. Pollut. Bull. 2021, 165, 112125. [CrossRef]

5. Hubbe, M.A.; Rojas, O.; Fingas, M.; Gupta, B.S. Cellulosic Substrates for Removal of Pollutants from Aqueous Systems: A Review. 3. Spilled Oil and Emulsified Organic Liquids. Bioresource 2013, 8, 3038-3097. [CrossRef]

6. Cojocaru, C.; Macoveanu, M.; Cretescu, I. Peat-based sorbents for the removal of oil spills from water surface: Application of artificial neural network modeling. Colloids Surf. A Physicochem. Eng. Asp. 2011, 384, 675-684. [CrossRef]

7. Li, H.; Li, Y.; Yang, W.; Cheng, L.; Tan, J. Needleless melt-electrospinning of biodegradable poly(lactic acid) ultrafine fibers for the removal of oil from water. Polymers 2017, 9, 3. [CrossRef] [PubMed]

8. Pintor, A.M.A.; Vilar, V.J.P.; Botelho, C.M.S.; Boaventura, R.A.R. Oil and grease removal from wastewaters: Sorption treatment as an alternative to state-of-the-art technologies. A critical review. Chem. Eng. J. 2016, 297, 229-255. [CrossRef]

9. Wang, Z.; Barford, J.P.; Hui, C.W.; McKay, G. Kinetic and equilibrium studies of hydrophilic and hydrophobic rice husk cellulosic fibers used as oil spill sorbents. Chem. Eng. J. 2015, 281, 961-969. [CrossRef]

10. Anjos, R.B.; Anjos, A.S.D.; de Juviniano, H.B.M.; de Dantas, T.N.C.; da Silva, D.R. Study of mandacaru (Cereus jamacaru dc), in natura and modified by microemulsion, as a biosorbent for diesel oil. Acta Sci.-Technol. 2020, 43, e49874. [CrossRef]

11. Annunciado, T.R.; Sydenstricker, T.H.D.; Amico, S.C. Experimental investigation of various vegetable fibers as sorbent materials for oil spills. Mar. Pollut. Bull. 2005, 50, 1340-1346. [CrossRef]

12. Deschamps, G.; Caruel, H.; Borredon, M.-E.; Bonnin, C.; Vignoles, C. Oil Removal from Water by Selective Sorption on Hydrophobic Cotton Fibers. 1. Study of Sorption Properties and Comparison with Other Cotton Fiber-Based Sorbents. Environ. Sci. Technol. 2003, 37, 1013-1015. [CrossRef]

13. Xu, Y.; Su, Q.; Shen, H.; Xu, G. Physicochemical and sorption characteristics of poplar seedfiber as a natural oil sorbent. Text. Res. J. 2019, 89, 4186-4194. [CrossRef]

14. Hilário, L.S.; Anjos, R.B.; Juviniano, H.B.M.; Silva, D.R. Evaluation of thermally treated Calotropis Procera fiber for the removal of petróleo on the water surface. Materials 2019, 12, 3894. [CrossRef]

15. Anjos, R.B.; Hilário, L.S.; de Moraes Juviniano, H.B.; da Silva, D.R. Petróleo removal using Calotropis procera. BioResources 2020, 15, 5246-5263. [CrossRef]

16. Thilagavathi, G.; Praba karan, C.; Das, D. Oil sorption and retention capacities of thermally-bonded hybrid nonwovens prepared from cotton, kapok, milkweed and polypropylene fibers. J. Environ. Manag. 2018, 219, 340-349. [CrossRef] 
17. Fabricante, J.R.; De Oliveira, M.N.A.; Filho, J.A.D.S. Aspectos da ecologia de Calotropis procera (Apocynaceae) em uma área de Caatinga alterada pelas obras do Projeto de Integração do Rio São Francisco em Mauriti, CE. Rodriguésia 2013, 64, 647-654. [CrossRef]

18. Andrade, M.V.M.; Silva, D.S.; Andrade, A.P.; Medeiros, A.N.; Pinto, M.S.C. Fenologia da calotropis procera ait r. br., em funçãodo sistema e da densidade de plantio. Archivos de Zootecnia 2005, 54, 631-634. Available online: https://www.redalyc.org/articulo. oa?id=49520805 (accessed on 17 February 2021).

19. Kaur, A.; Batish, D.R.; Kaur, S.; Chauhan, B.S. An Overview of the Characteristics and Potential of Calotropis procera From Botanical, Ecological, and Economic Perspectives. Front. Plant Sci. 2021, 12, 1188. [CrossRef]

20. Song, K.; Zhu, X.; Zhu, W.; Li, X. Preparation and characterization of cellulose nanocrystal extracted from Calotropis procera biomass. Bioresour. Bioprocess. 2019, 6, 45. [CrossRef]

21. Kissmann, K.G.; Groth, D. Plantas Infestantes e Nocivas; BASF Brasileira S.A.: São Paulo, Brazil, 1992; 798p.

22. Husseien, M.; Amer, A.A.; El-Maghraby, A.; Hamedallah, N. A comprehensive characterization of corn stalk and study of carbonized corn stalk in dye and gas oil sorption. J. Anal. Appl. Pyrolysis 2009, 86, 360-363. [CrossRef]

23. Barros Neto, B.; Scarminio, I.S.; Bruns, R.E. Como Fazer Experimentos, 4th ed.; Editora Bookman: São Paulo, Brazil, 2010.

24. Wei, Q.F.; Mather, R.R.; Fotheringham, A.F.; Yang, R.D. Evaluation of nonwoven polypropylene oil sorbents in marine oil-spill recovery. Mar. Pollut. Bull. 2003, 46, 780-783. [CrossRef]

25. Bazargan, A.; Tan, J.; Hui, C.W.; McKay, G. Utilization of rice husks for the production of oil sorbent materials. Cellulose 2014, 21, 1679-1688. [CrossRef]

26. Ribeiro, T.H.; Rubio, J.; Smith, R.W. A Dried Hydrophobic Aquaphyte as an Oil Filter for Oil/Water Emulsions. Spill Sci. Technol. Bull. 2003, 8, 483-489. [CrossRef]

27. Teas, C.; Kalligeros, S.; Zanikos, F.; Stournas, S.; Lois, E.; Anastopoulos, G. Investigation of the effectiveness of absorbent materials in oil spills clean up. Desalination 2001, 140, 259-264. [CrossRef]

28. Anjos, R.B.; Silva, W.P.N.; Silva, A.A.D.; da Barros, S.R.S.; de Carvalho Filho, E.V. Use of statistical modeling for BTEX prediction in cases of crude oil spill in seawater. Environ. Technol. 2021. [CrossRef]

29. Conselho Nacional Do Meio Ambiente-Conama. Resolução n 357, Dispõe Sobre a Classificação Dos Corpos de Água e Diretrizes Ambientais Para o Seu Enquadramento, Bem Como Estabelece as Condições e Padrões de Lançamento de Efluentes, e dá Outras Providências de 17 de Março de 2005. Brasília. 2005. Available online: http://www.mma.gov.br/port/conama/res/ res05/res35705.pdf (accessed on 17 July 2021).

30. Benini, K.C.C.C.; Brocks, T.; Montoro, S.R.; Cioffi, M.O.H.; Voorwald, J.C.H. Effect of fiber chemical treatment of nonwoven coconut fiber/epoxy composites adhesion obtained by RTM process. Polym. Compos. 2017, 38, 2518-2527. [CrossRef]

31. Yang, H.; Yan, R.; Chen, H.; Lee, D.H.; Zheng, C. Characteristics of hemicellulose, cellulose and lignin pyrolysis. Fuel 2007, 86, 1781-1788. [CrossRef] 